\title{
A DNA tool for the identification of heavily exploited Atlantic billfishes
}

\author{
Rodrigo R. Domingues ${ }^{1}$ - Gabriel Okuda ${ }^{2}$ Andrea M. Bernard ${ }^{3}$ - Alberto F. Amorim ${ }^{4}$. \\ Juliana De Biasi ${ }^{2} \cdot$ Alexandre W. S. Hilsdorf ${ }^{2}$
}

Received: 15 April 2015/Accepted: 18 August 2015/Published online: 27 August 2015

(C) Springer Science+Business Media Dordrecht 2015

\begin{abstract}
Due to the morphological similarities among species, the International Commission for the Conservation of the Atlantic Tunas has recommended the use of diagnostic molecular tools to allow for robust species-level identifications of the billfishes. In this study, a protocol for the molecular identification of all six Atlantic billfishes was developed utilizing a PCR-RFLP approach, targeting the mitochondrial gene cytochrome $c$ oxidase subunit 1 . A survey of 28 restriction endonucleases identified two enzymes (TaqI and HaeIII) that produced species-specific banding patterns sufficient to distinguish species. The protocol was validated against billfishes captured across their Atlantic distributions.
\end{abstract}

Keywords COI $\cdot$ PCR-RFLP $\cdot$ Genetics $\cdot$ Fisheries management $\cdot$ Pelagic fish

Electronic supplementary material The online version of this article (doi:10.1007/s12686-015-0489-4) contains supplementary material, which is available to authorized users.

Alexandre W. S. Hilsdorf

wagner@umc.br

1 Instituto de Biociências de Rio Claro, Universidade Estadual Paulista - UNESP, Av. 24-A, 1515, Rio Claro, SP 113506-900, Brazil

2 Núcleo Integrado de Biotecnologia, Universidade de Mogi das Cruzes, PO BOX 411, Mogi das Cruzes, SP 08701-970, Brazil

3 The Guy Harvey Research Institute, Oceanographic Center, Nova Southeastern University, 8000 N. Ocean Drive, Dania Beach, FL 33004, USA

4 Agência Paulista de Tecnologia dos Agronegócios, Instituto de Pesca, Av. Bartolomeu de Gusmão, 192, Santos, SP 11030-906, Brazil
Recent stock assessments suggest that all of the Atlantic billfishes (marlins: Kajikia albida, Makaira nigricans; spearfishes: Tetrapturus georgii, T. pfluegeri; sailfish: Istiophorus platypterus), except the swordfish (Xiphias gladius), are overexploited (ICCAT 2013). These species are caught incidentally by international industrialized fishing vessels, as well as by artisanal and sport fishers, making them important globally shared fish stocks (Ditton and Stoll 2003; Uozumi 2003). To prevent further declines, fishing regulations limiting the capture and commercialization of billfishes are required; however, enforcement requires accurate identification of all billfishes to the species level.

Two separate issues render accurate morphological species-specific identification difficult, leading to the widespread misreporting of catches. Firstly, fishers often remove the head and viscera subsequent to capture and secondly, only subtle morphological differences exist among $K$. albida, T. georgii and T. pfluegeri leading to their routine misidentification (Shivji et al. 2006; Beerkircher et al. 2009). To accurately identify marine fishes, molecular-based methods have proven useful. In particular, the DNA barcode approach, which targets a $\sim 650 \mathrm{bp}$ region of the mitochondrial protein coding gene cytochrome $c$ oxidase subunit 1 (COI), has become an invaluable tool to resolve species ambiguities (e.g., Ward et al. 2009; Hanner et al. 2011). However, sequencing can be costly and time-consuming compared to other methodologies such as PCR-RFLP. PCR-based methods have been developed to discriminate among the billfishes (e.g., Innes et al. 1998; McDowell and Graves 2002), no single approach is capable of discriminating among all six extant Atlantic billfish species. Herein, we developed a COI PCRRFLP approach to differentiate all six Atlantic billfishes, including the only recently validated roundscale spearfish (Shivji et al. 2006; Collette et al. 2006). 
Table 1 Genetic distance (Kimura 2-parameter) within and between billfishes from the Atlantic Ocean based on COI sequences from this study as well as sequences downloaded from FISH-BOLD

\begin{tabular}{|c|c|c|c|c|c|c|}
\hline COI & $X$. gladius & K. albida & T. pfluegeri & T. georgii & M. nigricans & I. platypterus \\
\hline$X$. gladius & 0.004 & & & & & \\
\hline K. albida & 0.192 & 0.002 & & & & \\
\hline T. pfluegeri & 0.187 & 0.031 & 0.001 & & & \\
\hline T. georgii & 0.180 & 0.033 & 0.020 & 0.002 & & \\
\hline M. nigricans & 0.189 & 0.022 & 0.031 & 0.038 & 0.004 & \\
\hline I. platypterus & 0.184 & 0.036 & 0.037 & 0.048 & 0.031 & 0.001 \\
\hline
\end{tabular}

To develop the COI PCR-RFLP method six Atlantic billfish COI sequences [one per species; 1559 bp; Genbank Accession Nos. HM071008-HM071009; HM071011HM071014; Little et al. (2010)] were aligned using the programs Clustal X v.2.0.12 (Larkin et al. 2007) and BioEdit v.7.0.9.0 (Hall 1999). To amplify a $\sim 1400 \mathrm{bp}$ region from all six billfish species for subsequent RFLP digestion, a universal billfish PCR primer pair was designed from conserved flanking expanses of the alignment using the programs Primer 3 v.4.0.0 0 (Koressaar and Remm 2007; Untergrasser et al. 2012) and Oligo Analyzer 3.1 (Integrated DNA Technologies Inc., Coralville, IA, USA) (FCOI_BSfish: 5'-TCTCGACCAATCACAAAGAC3'; RCOI_BSfish: 5'-TGTRGCGGTKAGTTCTACTG 3'). Using the universal primer pair, COI sequences were generated (Genbank Accession Nos. KR067396-KR067401) from tissue samples collected from 18 billfish specimens (three individuals per species) sampled from landings at Southeastern Brazilian fishing ports. All tissue samples were stored in $95 \%$ ethanol until genomic DNA extraction (DNeasy Blood and Tissue Kit, QIAGEN Inc.). COI PCR amplifications were performed using the universal primer pair and a reaction volume of $25 \mu \mathrm{L}$. PCRs contained: $20 \mathrm{ng}$ of DNA, 10X PCR buffer, $2.0 \mathrm{mM} \mathrm{MgCl}_{2}, 0.05 \mathrm{mM}$ of each dNTP, $0.7 \mu \mathrm{M}$ of each primer, and $0.625 \mathrm{U}$ of Taq polymerase (Fermentas Life Sciences). Amplifications consisted of: $95{ }^{\circ} \mathrm{C}$ for $2 \mathrm{~min}(\mathrm{~min}), 35$ cycles of $94{ }^{\circ} \mathrm{C}$ for $30 \mathrm{~s}(\mathrm{~s}), 54{ }^{\circ} \mathrm{C}$ for $30 \mathrm{~s}$, and $1 \mathrm{~min}$ at $72{ }^{\circ} \mathrm{C}$, and a final $5 \mathrm{~min}$ at $72{ }^{\circ} \mathrm{C}$.

Species-specific restriction site polymorphisms were identified within generated COI sequences via a survey of 28 restriction enzymes using the program NebCutter 2.0 (Vincze et al. 2003). Upon evaluation of the resultant restriction maps (data not shown), two restriction endonucleases [TaqI (recognition sequence 'T/CGA') and HaeIII (recognition sequence 'GG/GC')] generated clear banding patterns, which together, yielded a diagnostic pattern capable of distinguishing all six species (ESM 1). Furthermore, in silico analysis of the 248 COI Atlantic billfish sequences retrieved from FISH-BOLD found no evidence of intraspecific polymorphisms at any of the identified TaqI and HaeIII recognition sites, despite the analysis of a much broader geographic distribution of animals (i.e., Atlanticwide). Analysis of intra and interspecific difference showed low sequence variability within species (Table 1 ), which is consistent with findings of no variation at recognition sites. Failure to identify intraspecific variation at the restriction sites suggests that the species-specific diagnostic banding patterns generated using this suite of restriction enzymes will likely be consistent Atlantic-wide.
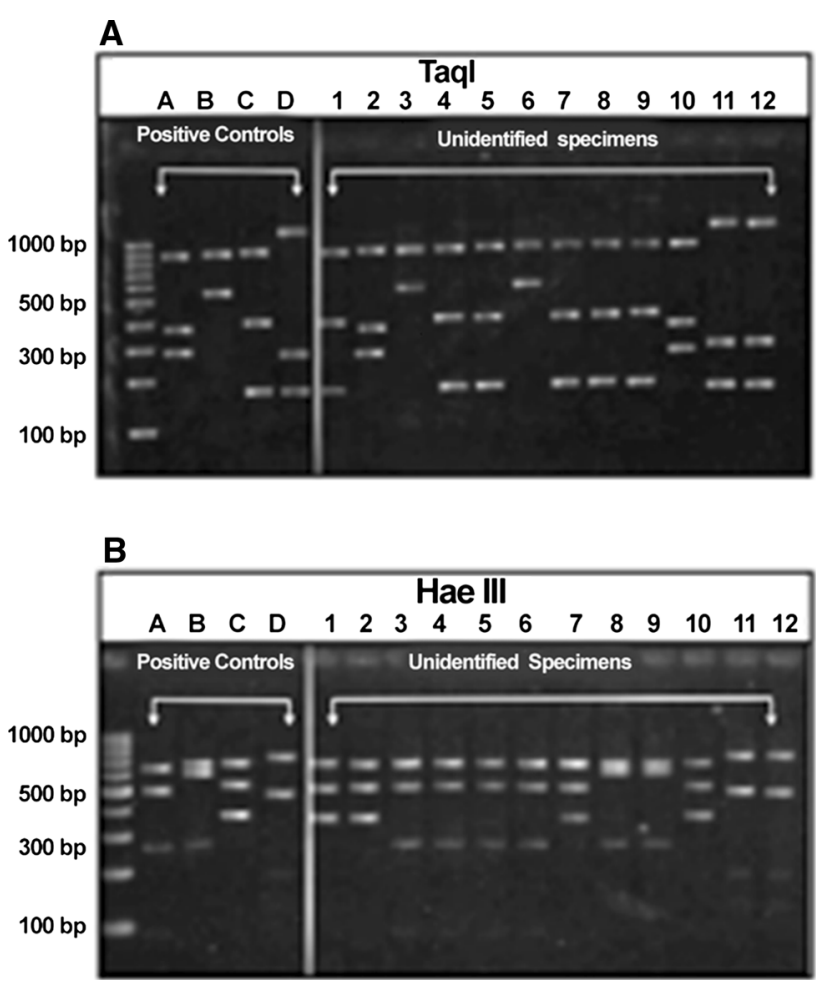

Fig. 1 COI PCR-RFLP patterns for the six Atlantic billfishes. a Digestions with TaqI. From left to right: 100 bp DNA ladder, Positive Control (PC) Pattern A (Tetrapturus georgii), PC-B (Kajikia albida), PC-C (T. pfluegeri, Makaira nigricans, and Istiophorus platypterus, and PC-D (Xiphias gladius), 1-12 unidentified samples. b Digestion with HaeIII. From left to right, 100 bp DNA ladder, PCA (Kajikia albida and Makaira nigricans), PC-B (Istiophorus platypterus), PC-C (Tetrapturus pfluegeri and Tetrapturus georgii), and PC-D (Xiphias gladius), 1-12 unidentified samples 
Table 2 Billfish species-specific banding patterns using the restriction enzymes TaqI and HaeIII

\begin{tabular}{ll}
\hline Species & Pattern TaqI/HaeIII \\
\hline Tetrapturus pfluegeri & $\mathrm{C} / \mathrm{C}$ \\
Tetrapturus georgii & $\mathrm{A} / \mathrm{C}$ \\
Kajikia albida & $\mathrm{B} / \mathrm{A}$ \\
Makaira nigricans & $\mathrm{C} / \mathrm{A}$ \\
Istiophorus platypterus & $\mathrm{C} / \mathrm{B}$ \\
Xiphias gladius & $\mathrm{D} / \mathrm{D}$ \\
\hline
\end{tabular}

Laboratory testing of the discriminatory power of the restriction enzymes was performed via digestion of COI PCR products using the restriction enzymes TaqI and HaeIII following manufacturer's recommendations. Electrophoresis of COI diagnostic fragments was performed on a $2 \%$ agarose gel using a $100 \mathrm{bp}$ DNA size standard (Invitrogen). Four distinct banding patterns were generated (Fig. 1). When combined, visual inspection of the two sets of banding patterns produced six species-specific haplotypes (Table 2) and was consistent across all replicates.

As tissue samples were only available from a small set of geographically restricted samples, to confirm Atlanticwide consistency of the banding patterns, 248 COI Atlantic billfish sequences (ESM 2, 3) from animals captured across their Atlantic distributions were surveyed for restriction site variations. No evidence of intraspecific polymorphisms was detected at any of the targeted recognition sites, suggesting Atlantic-wide applicability of the test. Further validation of the PCR-RFLP approach was performed via 240 anonymous species identifications using our COI PCR-RFLP methodology. Twenty people, unfamiliar with approach, identified 12 specimens (totaling 240 identifications), which yielded an overall success rate of species identifications of $100 \%$.

Use of our COI PCR-RFLP approach will enable accurate species-specific adult and larval identifications and abundance estimates, and will also allow for the monitoring of illegal trade across the entire Atlantic Ocean.

Acknowledgments Funding was provided by the São Paulo Research Foundation (FAPESP No. 2009/54660-6) and the Guy Harvey Ocean Foundation.

\section{References}

Beerkircher LR, Arocha F, Barse A, Prince ED, Restrepo V, Serafy JE, Shivji MS (2009) Effects of species misidentification on population assessment of overfished white marlin Tetrapturus albidus and roundscale spearfish T. georgii. Endanger Species Res 9:81-90

Collette BB, McDowell JR, Graves JE (2006) Phylogeny of recent billfishes (Xiphioidei). Bull Mar Sci 79:455-468

Ditton RB, Stoll JR (2003) Social and economic perspective on recreational billfish fisheries. Mar Freshw Res 54:545-554

Hall TA (1999) BioEdit: a user-friendly biological sequence alignment editor and analysis program for Windows 95/98/NT. Nucleic Acids Symp Ser 41:95-98

Hanner R, Floyd R, Bernard AM, Collette BB, Shivji MS (2011) DNA barcoding of billfishes. Mitochondrial DNA 22:27-36

ICCAT (2013) Report for biennial period, 2012-2013, part II vol 2. Madrid, Spain

Innes BH, Grewe PM, Ward RD (1998) PCR-based genetic identification of marlin and other billfish. Mar Freshw Res 49:383-388

Koressaar T, Remm M (2007) Enhancements and modifications of primer design program Primer3. Bioinformatics 23:1289-1291

Larkin MA, Blackshields G, Brown NP, Chenna R, McGettigan PA, William MC, Valentin F, Wallace IM, Wilm A, Lopez R, Thompson JD, Gibson TJ, Higgins DG (2007) Clustal W and Clustal X version 2.0. Bioinformatics 23:2947-2948

Little AG, Lougheed SC, Moyes CD (2010) Evolutionary affinity of billfishes (xiphiidae and istiophoridae) and flatfishes (plueronectiformes): independent and trans-subordinal origins of endothermy in teleost fishes. Mol Phylogenetics Evol 56:897-904

McDowell JR, Graves JE (2002) Nuclear and mitochondrial DNA markers for specific identification of istiophorid and xiphiid billfishes. Fish Bull 100:537-544

Shivji MS, Magnussen JE, Beerkircher LR, Hinteregger GF, Lee DW, Serafy JE, Prince ED (2006) Validity, identification, and distribution of the roundscale spearfish, Tetrapturus georgii (Teleostei: Istiophoridae): morphological and molecular evidence. Bull Mar Sci 79:483-491

Untergrasser A, Cutcutache I, Koressaar T, Ye J, Faircloth BC, Remm M, Rozen SG (2012) Primer3-new capabilities and interfaces. Nucleic Acids Res 40:e115

Uozumi Y (2003) Historical perspective of global billfish stock assessment. Mar Freshw Res 54:555-565

Vincze T, Posfai J, Roberts RJ (2003) NEBcutter: a program to cleave DNA with restriction enzymes. Nucleic Acids Res 31: 3688-3691

Ward RD, Hanner R, Hebert PDN (2009) The campaign to DNA barcode all fishes, FISH-BOL. J Fish Biol 74:329-356 